\title{
Which Person Is Presumed to Fit the Institution? How Refugee Students' and Practitioners' Discursive Representations of Successful Applicants and Students Highlight Transition Barriers to German Higher Education
}

\author{
Jana Berg
}

\section{Introduction $^{1}$}

Transitions into higher education are risky manoeuvres. Prospective students need to fulfil a number of formal criteria, are confronted with institutional expectations and yet have to figure out "the understandings, knowledges and practices needed to be successful in their studies" (Baker and Irwin 2019). While this concerns all students, some face additional obstacles and challenges which make them more likely to not enter or drop out of higher education. Research on higher education for refugees has shown a number of structural, institutional and individual aspects that hinder the hopes and goals of (prospective) refugee students. Overall, access to higher education can still be seen as stratified, even though equity in higher education has been an important topic on institutional and political agendas.

Education is a Human Right, "enshrined in the Universal Declaration of Human Rights (Article 26) and the United Nations Convention on the Rights of the Child (Article 28)" (UNESCO 2018: 43). The United Nations' sustainable development goal 4 seeks to "ensure inclusive and equitable quality education and promote lifelong learning opportunities for all” (United Nations 2015). Recently, the estimated worldwide number of refugees enrolled in higher education has gone up from 1 to $3 \%$. The UNHCR aims for that number to increase to $15 \%$ until 2030 (UNHCR 2019a). Responding to social inequalities and striving for equity in higher education is also among the goals for the further development of the European Higher Education Area (EHEA n.y.; EHEA Education Ministers 2018).

\footnotetext{
${ }^{1}$ This paper is based on research funded by the German Federal Ministry of Education and Research [01PX16015].
}

J. Berg (西)

German Center for Higher Education Research and Science Studies (DZHW),

Hanover, Germany

e-mail: berg@dzhw.eu 
In June 2019, there were 70.8 million displaced people worldwide, including 25.9 million refugees and 3.5 million asylum seekers. The majority remains in neighbouring countries. Nonetheless, Germany is among the 5 top refugee hosting countries (UNHCR 2019b). In reaction to their high levels of previous education and strong educational aspirations, the German Federal Ministry for Education and Research (BMBF) and many German states ('Bundesländer') launched funding schemes in order to support offers for (prospective) refugee students at German higher education institutions (HEI), allowing many HEI to formalize their previously often voluntarybased offers for refugees (DAAD 2018). In 2016 and 2017, over 14,000 refugees and asylum seekers participated in federally funded study preparation courses (Fourier et al. 2018). High numbers of asylum seekers and refugees as well as a large variety of support programs and integration initiatives make Germany an interesting case for investigating higher education for refugees.

In order to support refugees' access to higher education, it is necessary to understand their situation and the conditions of their transition into higher education: "effective transitions require a better understanding of how people progress cognitively, emotionally and socially between different subjects at different stages of their learning, and how they navigate the complex demands of different contexts" (Ecclestone et al. 2010: 6). This paper seeks to contribute to this understanding by investigating the discursive understandings of successful students as a form of knowledge that implicitly highlights access barriers to higher education. It aims to identify the characteristics of successful students from the perspective of experts as well as (prospective) refugee students.

The main research questions are:

- Who is a successful student understood to be?

- How does the situation of refugee students differ from this ideal?

- Which (implicit) barriers are referred to via those understandings?

First, I will discuss understandings and attributes of higher education transitions (2) and describe my theoretical and methodological presuppositions (3) as well as the data and methods this paper is based on (4). Then, I will address the first research question and give an overview of aspects of an ideal transition as described and implied by my interview partners (5.1) and briefly show where they see refugees' situations to differ from this ideal (5.2). Referring to the second research question, I will discuss institutional presumptions as an important access barrier to higher education (6) and end with a working hypothesis. Finally, I recommend that institutional settings should develop more awareness of and adapt to diverse applicants and students in order to widen access to higher education (7).

\section{Higher Education Transitions}

"Access to HE contributes both to the reproduction of social structures/organisations and their transformation" (Goastellec and Välimaa 2019: 3). As facilitators of social stratification as well as social change, higher education transitions and related 
questions of access, inequality and equity as well as widening participation can individually, institutionally and politically be understood to be critical and have been receiving a lot of academic and political attention (Ecclestone et al. 2010; Détourbe 2018). Regardless of continuous political and institutional efforts for equity in higher education, inequalities remain (Goastellec and Välimaa 2019), and groups struggle to access, obtain and succeed in higher education.

Researchers have used various ways of defining and theoretically approaching transitions. In broad terms, transitions are understood as "a process of change over time" (Colley 2010:131) and often connected to changes in peoples' "sense of who they are" (Ecclestone et al. 2010: 2). In addition to identity, agency and structural conditions shaping it are seen as important factors but also outcomes of transitions. Transitions are understood as closely connected to, or even as the "product of social institutions [as well as] social expectations" (Ecclestone et al. 2010: 5).

Regarding "the transition to higher education, we could say that educational transitions are any major changes in students' role requirements or study context. The transition from secondary to higher education is clearly a change regarding the study context (i.e. new institution, for some students, also a new city and living on their own) as well as a change in what is expected of students (i.e. their role, e.g. a more self-responsible organisation of their studying in regard of content, time and study mode)." (Coertjens et al. 2017: 359)

Literature on higher education transitions discusses a number of factors influencing the outcomes of transition processes. As Coertjens et al. sum it up, research on transitions into higher education has focussed on the "development of a student identity, [effects of] student engagement [the] fit between secondary and higher education [and] students' motivation [as well as] emotions [and] learning approaches" (Coertjens et al. 2017: 360f.). Colley (2010) argues to also take a sociological understanding of time into account when dealing with education transitions and Ecclestone et al. (2010) discuss the importance of agency, identity and structure. Also, knowledge of institutions and norms regarding the transition process, in other words, the "academic practices and navigational knowledge that students are assumed to have/bring to their studies." Baker and Irwin (2019: 16) has been discussed as an important factor. It seems important to note that a transition "is not a neat, unifying package containing skills or competencies, and neither is it a neutral description of a temporal or spatial linear process" (Taylor and Harris-Evans 2018: 1265). Instead, higher education transition "is a dynamic, multiple, creative and mobile assemblage which changes with individual context, experience and instance, and is entangled with embodied, affective and cognitive ways of coming to, and becoming within, university" (ibid.). Therefore, research should be open to individual experiences, trajectories and influencing factors (Baker and Irwin 2019: 16f.). The understanding of "educational attainment [a]s determined by movement through 'an ordered sequence of educational transitions" Ecclestone et al. (2010: 6) does not take the variety of pathways into higher education into account.

The importance and, partly, also the interconnectedness of structural, institutional and individual factors and their importance for access to higher education have been discussed in a variety of studies (Goastellec and Välimaa 2019). Walker (2019) 
and Grüttner et al. (2018) discuss conversion factors that influence and determine higher education transitions, following Sen's capabilities approach. Sommet et al. have emphasized the importance of a person-institution fit, especially referring to "competitive institution's culture, practices, and identity" (2015: 1), and Baker and Irwin (2019) argue for a better understanding of knowledges and practices that are normalized in and demanded by Western HEI.

Another debate concerns the timeframe of higher education transitions. While Coertjens et al. suggest to include the time "from the last year of secondary education till after students' first experience with formal assessment in higher education" (2017: 360), this definition does not account for prospective students who apply after a gap in their educational biography, or those who (have to) take institutional detours in order to access higher education, such as non-traditional students or international students in study preparation.

\subsection{Study Preparation: An Educational Phase During Higher Education Transition}

In case foreign school or university certificates are not acknowledged as higher education entrance qualification, international students have to take an assessment test ('Feststellungsprïfung') in order to apply for German HEIs. Preparatory colleges ('Studienkollegs') prepare international students for this test in field-specific courses. The course determines a range of fields (such as technical or medical subjects) that can be accessed after the respective assessment test. Regardless of its importance for many non-EU international students, this specific educational phase of formal study preparation has only received little academic attention (Berg et al. 2019a).

Refugees have been noted to have strong educational aspirations but also to face interdependent challenges, and even though it is a diverse group, they are assumed to share structural similarities in challenges and needs, often related to a new educational system, cultural environment, language proficiency and missing or not acknowledged social and cultural capital (Grüttner et al. 2018; Ramsay and Baker 2019; Berg et al. 2018). In response to the influx of newly arriving asylum applicants in 2015 and ' 16 , German HEIs and preparatory colleges started additional offers for refugee students (Berg 2018; Unangst 2019). The support was mostly based on voluntary pioneerengagement and got formalized, mostly using public funding schemes, such as the federal projects 'Integra' and 'Welcome' as well as programs on state-level (Berg et al. n.y.). These offers often focus on study-preparation as well as social integration of refugees and seem designed to support refugee students to fit the institutional environment they aim to apply for Berg (2018).

This paper is investigating the perspective of refugee students taking part in such preparatory courses as well as experts whose counselling-or teachingpositions are related to the transition of refugees into German higher education. Their constructs of successful students are described as an indicator of access 
barriers to higher education. The analysis is based on the presumption of discourses as representations of social norms, which will be further described in the next section.

\section{Theoretical and Methodological Presuppositions}

In order to look into higher education transitions for refugees, I understand them as the time and practice of navigating through institutional requirements and conditions towards becoming a student_-formally as well as by developing a student identity. This understanding is oriented on the goal and end of higher education transition and purposefully does not define a number of institutional settings or a time-frame, but aims to be open for individual trajectories and experiences of prospective refugee students. It also emphasized how risky and critical transitions are, since their outcome defines them but remains unclear throughout the transition itself. Institutional and social norms as well as personal background, experiences and knowledge are understood as crucial factors in a norm-person-institution interplay.

\footnotetext{
"Access to HE is multifaceted because it includes the provision of study places (HEIs and their geography, the educational system HEIs are embedded in), student' influx patterns and students' characteristics. Admission refers to processes sustaining or restraining students' access on the basis of a variety of criteria (social, economic, academic) and procedures (former degrees, exams, tests, ability to testify one's social position and, more broadly, one's social characteristics)." (Goastellec and Välimaa 2019: 4)
}

This navigation requires and is influenced by understandings and knowledges of social and institutional norms. In this paper, I focus on discursive representations of 'normal successful students' as a form of knowledge that highlights access barriers to higher education.

Discourse analysis is based on Foucault's assumption that "language use constitutes its subjects as knowledge in discursive practices" (Keller 2007: 2, original quote in German). It aims to interpret, categorize and thus reconstruct discourses, their creation and alterations, their relation to social practices, as well as social actors' strategic discursive performances (Keller 2007: 6, 2011: 188). Therefore, instead of focussing on interpretations of individual actors, discourse analysis is looking for their references to general discourses.

\section{Data and Methods}

\subsection{Sampling and Interviews}

This study is based on episodic interviews with 11 prospective refugee students as well as 5 expert interviews with the university's first contact for refugees, who counsels and coordinates offers for refugees, a social counsellor, a general student 
counsellor, as well as teachers of preparatory courses at both the university and the preparatory college in one city in Germany. All interviews were conducted within the 'WeGe'-research-project on refugees' pathways to German higher education. The research interest of this paper emerged during further analysis after the interviews were conducted. While the interviews were conducted by the WeGe-project-team, this paper is based on the author's additional interview analysis.

Nine of the interviews with refugee students were conducted in late 2017, and two in early 2019. They participated in study preparation courses at a university or preparatory college. To prepare the interviews, we reviewed literature on ethical research with refugees and developed a project-specific awareness strategy, which can only be summarized here (Berg et al. 2019b,c). Our aim was to create a respectful and trustful research environment and open communication with our participants. This included being open about our work and aims and preventing false hope about potential benefits of participation. Another important aspect was to reduce similarities to interviews that are conducted during the German asylum process. Therefore, we strongly focused on educational aspects and did not inquiry on personal histories of forced displacement, but also offered space if the interviewees addressed their experiences of forced migration. Access to study preparation already depends on a certain level of German proficiency. It is also the language that the investigated field of higher education and study preparation is mainly presenting itself to the participants. In order to acknowledge the language skills they already have, we therefore conducted all interviews in German. Many interviewees stated that using the interview as an opportunity to practice their German was one important reason to participate.

We aimed to represent diverse perspectives by sampling based on gender, age and countries of origin. The interviews chosen for this paper also differ regarding their previous educational experiences, their aspirated subjects and their residential status. We generally followed the participants' self-definition as refugee students. We conducted interviews in general, as well as refugee-specific courses. All interviews included in this paper have been conducted with asylum seekers or people with some sort of refugee protection.

The participants were either contacted during short presentations at preparatory courses, by their teachers or other gatekeepers, depending on possibilities at individual courses. Firstly, an informed consensus, including information on data protection, was provided in English and German and explained by the researcher, as well as signed by the researcher and the participant. After all potential questions were answered, the interviews were conducted. The guideline included questions on their educational biography, the preparation courses, teaching and learning styles, motivation to study, personal networks and living conditions, challenges and support, the relevance of their legal status as well as hopes for the future. While no explicit question on successful students or ideal study situations were asked, one question was included on what they considered important for being able to start studying after the course. 
The expert interviews were conducted in late 2017. Practitioners were sampled based on their professional position's connection to access to higher education. For each profession, individual interview guidelines were developed. They included questions on their professional contact to and perspective of refugees, existing support structures at their institution, their networks and sources of information on refugees, specific challenges for refugee students and further, profession-dependent questions on tasks and related experiences.

\subsection{Interview Analysis}

As mentioned above, the research interest for this paper developed during the analysis of interviews conducted within the WeGe-project. Based on the new research question, I started an additional analysis. The analysis was based on Keller's approach to discourse analysis, which is closely connected to the sociology of knowledge and oriented on aspects of grounded theory methodology. To analyse the interviews, I firstly used open coding in order to get an idea of aspects concerning ideal successful study applicants and students, as well as to where students see their own situation, or experts describe refugees' situations as different from this ideal. The ideals were directly mentioned or indirectly mentioned with differentiations, apparently self-evident reasoning etc. While during the first interviews the number of codes increased rapidly, the open coding of the last few interviews mostly enriched existing codes. This was seen as an indicator for satiation, so no further interviews were included. Also, it quickly became apparent that not only the personality or individual characteristics of successful applicants and students were discussed, but also their environment and activities, which led to the expansion of the research interest from 'who is a successful student understood to be' to 'what are the assumptions about an ideal higher education transition'. Based on the open coding, I reconstructed the phenomenon structure ('Phänomenstruktur') by outlining its dimensions and its content (Keller 2007: 15f; 21). Axial coding was used to sort the codes into the phenomenon structure ('Ordnung der Phänomenstruktur'). Based on selective coding, relevant codes, their interconnectedness and storyline were analysed as narrative structures ('narrative Strukturen'). Based on a table that provided overviews of the phenomenon structure in interviews with refugee students and experts, I compared and connected the results for both groups of interview partners.

\subsection{Limitations}

Regarding the limitations of the study, it should be noted that all sampled refugee students are already participating in study preparation courses. This means they have already decided to aim at higher education and could successfully gain access to study preparation programs. Some of them even got preliminary admitted to a HEI. 
Therefore, candidates that got rejected or decided not to apply as well as those that could access higher education without study preparation courses are not represented.

Even though the sampling focusses on one regional case study, it inductively seeks to provide an insight to general discourses by extrapolating from individual cases to general discourses. Nonetheless, regional, institutional and individual factors could further influence this discourse and produce aspects of it that are not present in this case study.

\section{Findings}

This section deals with the first two research question of who a successful student is understood to be and where the situation of refugee students differs from this ideal. From direct descriptions of how university studies work or what students should do to implicit references to an ideal situation-all interview partners seemed to have an understanding of successful students and 'normal' pathways to higher education. Those explicit and implicit referrals can be understood as representations of discourses on ideal higher education transitions. Individual statements referred to several stages of transition: study preparation, application and access as well as studying. They give an overview of skills and knowledges that are (assumed to be) either needed during or have to be developed throughout the transition.

It can generally be stated that all interviewees described applicants' high obligations of personal engagement and high individual responsibility for the outcomes of study applications but, on the other hand, also saw institutional obligations to support applicants and students. The following paragraph (5_1) addresses aspects of the discourse on ideal transitions. They include applicants' and students' characteristics, practical skills and knowledges, structural and social as well as institutional conditions and prospective outcomes of successful higher education transitions. In contrast to those aspects, the next paragraph shows how the situation of refugee students often differs from those ideals (5_2).

\subsection{Perceptions of the Ideal Student and Study Transition}

When it comes to the characteristics of successful students, they are understood to be physically and psychologically healthy, highly motivated and well organised. Both practitioners and refugees mentioned that students should be well-rested. This was brought up in the contexts of psychological wellbeing and housing. Young applicants are described to have better chances due to better learning abilities and more recent experience with formal education. Younger students are also understood to receive better support. 
"Age plays an important role in Germany. And that's why the State supports the young people, or rather until 25. That is important. [...] And one can see, one gets child support until around 27, 26? I don't know exactly. But this has a reason. The people who can become something have to make it until that age. If not, then not. That is understandable. For Germany, too. For foreigners I don't say that, but for Germans. “ (Refugee Student 2interviews are chronologically numbered. All quotes translated by the author)

Fluent (German) language skills are mentioned in every interview-they are described as crucial to follow and fully understand lectures, to interact with others and are closely linked to formal access requirements as well as sound study preparation.

As Muslim holidays and traditions are mentioned to not fit the schedule of some programs, it could indirectly be concluded that an ideal transition is easiest for Christian or atheist students, whose habits fit German holidays and conventional schedules.

"Only in late May Ramadan started and then the participant numbers very much collapsed. [...] It was in the afternoon; they just did not show up anymore. And suddenly we had 15-20 participants, instead of previously 40. [...] I know that now for next year, for Ramadan there has to be a break for this course. [...] At the university, this break does not exist, but because we are targeted to this group, it does not work, yes?" (Teacher and math preparation course coordinator, University)

Refugees also mention personal talent for the field of study. Further, they describe the ability of never giving up against all odds which can be understood in the context of a necessary resilience. A practitioner additionally emphasized the need to be adaptable to unforeseen changes and a new institutional environment. One refugee student mentioned exam anxiety as a challenge which leads to the conclusion that, ideally, students have the skill to take exams calmly, focussed and anxiety-free.

Successful students are described to need a number of practical skills and knowledges. They have to be very self-sufficient and autonomous. This includes organising their everyday life while living alone, gathering all relevant information regarding formal transition requirements, student life etc. and successfully completing study preparations (if necessary). In this context, language proficiency is connected to the ability to formulate (academic) texts, understanding and using technical terms, as well as presentation skills.

Also, successful students should be disciplined learners with certain knowledge of learning strategies such as learning in groups, critical and curious questions and organised learning materials. They should also be aware of and prepare for specific information and knowledge important to their (desired) fields of study. This requires further skills and practices, such as forming groups, but also refers to social networks and institutional environments:

"So maybe at the university? They do those groups. They have to consider a little that we as foreigners are not as used to this as Germans. For example, they [...] say 'yes, you have to do a group. You have to do a presentation.' But you look and the others, maybe a group, they are already enough. And you want to go to another group and they don't want you. And the professor says: 'Yes, you have to look for this yourself." (Refugee Student 5)

This leads to the next section, the structural and social conditions of successful higher education transitions. Ideally, applicants and students can focus only on their 
application and further education. This includes being supported by their families (Shapiro 2018) without being put under pressure or having family responsibilities of their own, as well as financial security to the point that only minor jobs are necessary if any. In this context, it would also mean not having to worry about the legal status and residence security. Refugee students emphasize the importance of emotional, institutional and financial support. Many interviewees also point out housing as a crucial factor: it is important to live or be able to move closer to the HEI, and the quality of housing determined the learning environment. Also, social surroundings are understood to make a great difference. Repeatedly, an academic family background is mentioned as helpful, and family and friends are described as important support. One teacher mentioned that successful students should stay away from bad influences:

"So this one young man, who also was absent rather often, he had made some friends. [...] In this course, who also frequently skipped class. And this was such a clique, he should have better picked others. [...] And he did not make [the test]. And had to repeat [the class]." (Teacher, Preparatory College)

Relevant institutional conditions concern institutions visited before applying as well as HEIs. Generally, applicants are assumed to continue from secondary to tertiary education with no gap in their educational biography. The benefits of transitioning more or less directly from high schools include familiarity with formal education, fresh and trained learning strategies as well as study preparation that is supposed to closely fit the respective higher education system. Few interviewees also mention the benefits of private schools. In case study preparation courses are necessary, they should be taught by professionally trained experts in the field and be of high quality while addressing academic and language needs. They need to be well organised because they need to cover many aspects in a rather short time.

Regarding further transitions into HEIs, successful applications have to fulfil a number of formal criteria, including entrance qualification documents, proof of German language proficiency, but also English language skills, proof of social insurance and further, subject-related criteria, including very high grades. The institutional environment and related support structures are shaped by institutional assumptions about 'normal' applicants and students:

"And we noticed last summer during orientation week: Oh man, there are really many with refugee background, which we think it great. [...] But when it comes to, how do I apply. Meaning, presentations about application procedures are not completely different for non$E U$-citizens. And then there sat the first refugees and were slightly frustrated that there was nothing about their topic. We just did not think of them, because it was a classical information day for people fresh out of high school. And we briefly felt really bad." (Study Counsellor, University)

Finally, it seems important to apply for a fitting institution. Some counsellors mentioned referring prospective students to other higher education institutions with more fitting programs.

"We often refer to certain programs at [HEI]. They are relatively accommodating, a little less complicated than [HEI], I would say. Very friendly staff as well. And so, we exchange 
people when we think it might be a better fit. Whether they do it, they have to decide for themselves." (Study Counsellor, University)

Successful studies are understood to heavily increase future employment and salaries throughout the interviews. Other outcomes described by refugee students are proud families, the possibility to contribute to society and personal development, including an increased understanding of possible jobs, but also life-long learning and improved abilities to understand and reflect.

"Yes, it is always good if one has a capacity, a Bachelor level. So, if one is at bachelor level, he also thinks a bit differently, because of the knowledge. Meaning, he knows much. So he can plan more. And if parents have a child, and this child has a Bachelor degree, or a Master degree, then he is happy. Exactly, when one is successful." (Refugee Student 4)

Further, some refugee students hope to increase their chances of staying in Germany by studying successfully.

The practitioners additionally mention happiness and life satisfaction as studentoutcomes. They note that domestic students often look for self-fulfilment, while refugee students are often more closely oriented on future chances on the labour market, without rating those different motivations. While being a foreigner was generally understood to complicate higher education transitions, student mobility was repeatedly mentioned as desirable.

\subsection{Far from Ideal: Where Refugee Students' Situations Differ from 'Standard' Transitions}

Many of those representations of ideal higher education transitions are based on quite contrasting descriptions of the situation of refugee students. While individual situations differ heavily, this section deals with the striking differences to the ideal situation that were mentioned throughout all interviews. It is important to note that this is not a differentiation of refugee students from domestic students or international students with no experience of forced migration but from a hypothetic ideal. Since many aspects have been described extensively in the broad literature on challenges for (prospective) refugee students (Crea 2016; Halkic and Arnold 2019; AbduRazak et al. 2019; Grüttner et al. 2018), I will provide a broad overview of differences to an ideal. In the context of this paper, those differences are important because they are noticed by refugee students and practitioners and could impact their actions.

Generally, refugee students describe and are described as facing a very different situation than most domestic students.

"They simply face additional challenges. It just is a foreign country. The language is not the native language. The friends are not the same. The living-conditions are simply harder. And when they also have demanding studies and also have to work so much, it is [...] indeed compromising success." (Study Counsellor, University) 
The described differences to an ideal transition always concern extensive institutional detours in connection with additional bureaucratic effort. The latter includes the formal necessity of study preparations, the inclusion in the highly bureaucratic German asylum system, the additional effort of learning the language and getting to know a new culture and education system as well as difficulties in obtaining comprehensive and correct information. Also, the quality of preparatory courses is sometimes described to be rather poorly, partly because of unfit or not specifically trained teachers.

Another major concern is housing. Many refugees report living too far away from their study preparation and prospective HEIs. Also, shared rooms and crowded common areas are described to inhibit individual learning processes. Many refugees struggle to finance their studies. This is especially hard for asylum seekers and everybody not eligible for public student funding. Often, refugees are older than other applicants and students and must re-build academic knowledge and learning strategies after (forced) gaps in their educational biography.

Refugee students' individual situations differ in many ways, depending on factors such as gender, family background, country of origin, educational biography and many more. Among individually described differences from transition ideals are absent family, responsibility for children and household, no academic background, social isolation and difficulties with the forced independence and self-sufficiency as well as mental health issues (Grüttner et al. 2018).

"And then it turned out that they often could not really study anymore. They [...] hardly slept anymore. They have, no idea, lost almost all their fellow students, the family was displaced and then we just noticed that they experienced insanely much stress and indeed showed [...] health-relevant or sickness-relevant effects of this Syrian crisis." (Social Counsellor, University)

Strikingly, many refugees mentioned that they had been recommended to enter jobs or vocational training instead of studying.

"People have also said: 'Vocational training is very simple. You can read, your German is suitable for vocational training. You can find a spot immediately.' I have said: 'Actually, I absolutely, I want to study." (Refugee Student 8)

This could likely impact their estimation of the difficulties and possibilities of higher education and heavily influence their decision making and implies that high commitment can be an important factor for successful higher education transitions of all groups that are likely counselled not to study. One refugee student describes his strategy of dealing with those situations:

"They do not want you to study. If you go to study, you are away from the Jobcenter. They do not belong to the Jobcenter anymore. Yes, rather do not ask. [...] One should [talk] to people that support this. If I know that when I say 'I want to study medicine' and they answer 'yes, okay, great, this is good'. Then I should talk to them. But when they say 'no, medicine takes too long', then I should not talk to them." (Refugee Student 9)

Refugees report several worries about not being able to deal with the multitude of challenges. Some fear deportation or struggle with the need to frequently renew their 
legal status and describe stress and related psychosomatic effects. Others mention that even if they successfully pass study preparations, they are afraid that not enough study places will be available and they might eventually not gain access to higher education. They also feel like they are wasting time and partly put themselves or were externally put under a lot of pressure to make up for 'lost' years (Baker et al. 2019).

Interestingly, being a refugee was almost exclusively discussed in the context of obstacles and challenges and separated from possible student identities. Previous studies are mentioned as a motivation to continue higher education and as subjectselection-criteria, and sometimes as a source of academic experience, knowledge and skills. Nonetheless, forced time during forced migration seems to be a different stage of living and is mostly connected to detours and lost time (Klaus 2020).

\section{Discussion}

While the first two research questions have been addressed in Sect. 5, this section discusses the third question: Which (implicit) barriers are referred to via those understandings?

The topics emerging in the research presented in this paper can be understood as representations of transition barriers that, to some degree, can likely be applied to various groups of, if not all, students. Applicants' and students' characteristics, their practical skills and knowledges, but also structural and social as well as institutional conditions shape higher education transitions of refugee students in Germany. Applicants and students are expected to have certain characteristics, such as high motivation, resilience and self-sufficiency. They are sometimes assumed to be mainly responsible for their individual transition, including its outcome (Colley 2010: 132). While some refugee students and all practitioners refer to the importance of institutional support, the self-sufficiency and individual responsibility are mentioned and implied throughout the interviews. This can create additional pressure and lead to misrepresentations of structural challenges as individual tasks and distract from social power dynamics:

\footnotetext{
"Since 'power relations are crucial in defining the situation of refugees' (Dryden-Peterson and Giles, ibid.), these authors show that refugees do not fit in the neoliberal picture of students as 'self-directed agents of all classes who can effectively navigate the postindustrial knowledge economy, able to both meet the skills needs of the economy and experience social mobility' (ibid.): their ability to make informed choices is hampered by 'the unequal social relations and multiple discourses within which [their] aspirations and knowledge are embedded and formed' (Dougherty and Callender 2017, p. 8). In other words, their probability to access HE can be considered as 'the product not so much of lesser desire or ability but of societal and institutional obstacles and exclusions that negatively shape disadvantaged students' aspirations, knowledge, and academic preparation' (ibid., p. 43)." (Détourbe and Goastellec 2018: 4)
}

One important aspect of transitions is their timing. Firstly, as Ecclestone et al. (2010: 5f.) argue, there are numerous, if not constant transitions throughout the life course, 
usually associated with a certain age and an expected order. Formal procedures and expectations are built on those assumptions which can lead to complications in case they are not met:

"In this context, I find it problematic [...] that the BAföG[public financial student support]law is a law that had initially been built for [...] German students. And study delays that are caused by the circumstance that some is not native speaker. Those cannot be considered for $B A f o ̈ G . "$ (Social Counsellor, University)

Secondly, cultural or religious organisations of time are described to create issues of unexcused absence in preparatory courses. Generally, institutional assumptions can be understood as a crucial factor of higher education transitions. This concerns academic and institutional knowledge but also broader cultural assumptions about epistemology, study culture, student identity, self-organisation and learning styles (Baker and Irwin 2019; Coertjens et al. 2017; Colley 2010). Those assumptions can create serious challenges for all that do not meet them. In this context, it should be mentioned that the intersection of different policy areas, such as higher education, welfare or asylum, and of related institutions can cause additional issues for prospective students (Détourbe and Goastellec 2018; Grüttner et al. 2018).

When it comes to institutions, it is also important that formal education obtained before higher education fits HEIs' education (Coertjens et al. 2017: 361). This emphasizes the importance of ensuring high-quality study preparation.

The discourse representation of ideal higher education transitions can also be seen as a barrier in itself. Overall, the research presented in this article can be understood to lead to the following working hypothesis: The further an applicant's situation differs from generally assumed ideal higher education transitions, the more likely this applicant will confront difficulties or even not complete the transition. This could be related to an unfitting institutional environment, HEI actors' estimations of the applicant as unfit and also the applicant's own perception of the transition's costs, benefits and likelihood of success. To work with this notion means not only to address the challenges of diverse groups and the relevance of institutional environments for those challenges, but also to question the presumptions that shape institutional environments and-in this case- the norms of transition.

\section{Implications}

"For students who are still developing proficiency in the dominant language of their resettlement country [...], universities have a 'moral imperative' (Lenette 2016) to support the development of their language, literacies and cultural practices." (Baker and Irwin 2019: 17)

In order to support their higher education transitions, it seems crucial that students with diverse experiences and identities are not uniformly confronted with institutional expectations and normative discourses far off their own situation. HEI and educational policy should be aware of the variety of (prospective) students. Assessments of their diverse realities, experiences and challenges, but also strengths (Harvey and 
Mallman 2019) and capabilities could help HEI to create more flexible practices and a new discourse representing more diverse access routes to higher education. This should be accompanied by the availability of individual and personal counselling (Baker et al. 2018). Since many students deal with issues that cannot directly or only limitedly be addressed by HEI, such as housing, further networks, information exchange and cooperation seem to be increasingly important.

Some studies have also addressed the importance of role models (Bajwa et al. 2017). Throughout the interviews, peers, friends and other students were named as important sources of information and in some cases also inspiration by refugee students. Thus, it can be seen as helpful to provide peer counselling, support peer contact and publicly represent a diverse student body.

Once they entered higher education, students should be well trained in expected knowledges and academic practices. This does not only include academic writing, etc., but offers should also be aware of students' unfamiliarity with the "epistemological practices" (Baker and Irwin 2019: 14) of the academy.

Finally, it seems important to note that transitions that do not lead to HEI, but other transitions and institutions that fit interests and personal development should not generally be understood as failed. Nonetheless, structural disadvantages for groups that often face transition challenges should be met with structural support.

\section{References}

AbduRazak, L. F., AL Mawdieh, R. S., Karam, A. A., Yousef Aljaafreh, A., \& Elias Al-Azzaw, M. (2019). Determining the Challenges Faced by Syrian Refugees Students at Jordanian Camps According to Their Perspective: A Case of Universities Role to Supporting. Modern Applied Science, 13(8). doi: 176. https://doi.org/10.5539/mas.v13n8p176.

Bajwa, J. K., Couto, S., Kidd, S., Markoulakis, R., Abai, M., \& McKenzie, K. (2017). Refugees, Higher Education, and Informational Barriers. Refuge, 33(2), 56-65. https://doi.org/10.7202/ 1043063ar.

Baker, S., \& Irwin, E. (2019). Disrupting the dominance of 'linear pathways': how institutional assumptions create 'stuck places' for refugee students' transitions into higher education. Research Papers in Education, 12(1), 1-21. https://doi.org/10.1080/02671522.2019.1633561.

Baker, S., Ramsay, G., Irwin, E., \& Miles, L. (2018). 'Hot', 'Cold' and 'Warm' supports: towards theorising where refugee students go for assistance at university. Teaching in Higher Education, 23(1), 1-16. https://doi.org/10.1080/13562517.2017.1332028.

Baker, S., Irwin, E., \& Freeman, H. (2019). Wasted, manipulated and compressed time: adult refugee students' experiences of transitioning into Australian higher education. Journal of Further and Higher Education, 7(1), 1-14. https://doi.org/10.1080/0309877X.2019.1586849.

Berg, J. (2018) A New Aspect of Internationalisation? Specific Challenges and Support Structures for Refugees on Their Way to German Higher Education. In A. Curaj, L. Deca, \& R. Pricopie (Eds.), European Higher Education Area: The Impact of Past and Future Policies, (pp. 219-235). Cham: Springer International Publishing.

Berg, J., Gottburgsen, A., \& Kleimann, B. (n.y.). Formalising Organisational Responsibility for Refugees in German Higher Education: The Case of 'First Contacts', Submitted Manuscript.

Berg, J., Grüttner, M., \& Schröder, S. (2018). Zwischen Befähigung und Stigmatisierung?: Die Situation von Geflüchteten beim Hochschulzugang und im Studium. Ein internationaler Forschungsüberblick, Zeitschrift für Flüchtlingsforschung, 2(1), 57-90. 
Berg, J., Schröder, S., \& Grüttner, M. (2019a). Studienvorbereitung für Geflüchtete in DeutschlandHerausforderungen eines besonderen Bildungsabschnitts. Schulheft 176(Reihe), 132-137.

Berg, J., Grüttner, M., \& Schröder, S. (2019b). Zwischen Partizipation und Retraumatisierung (Selbst-)kritische Überlegungen zur Forschung mit Geflüchteten. In N. Burzan (Ed.), Komplexe Dynamiken globaler und lokaler Entwicklungen - Verhandlungen des 39. Kongresses der Deutschen Gesellschaft für Soziologie in Göttingen 2018, DGS.

Berg, J., Grüttner, M., \& Schröder, S. (2019c). Entwicklung und Anwendung eines Sensibilisierungskonzeptes für qualitative Interviews mit Geflüchteten - Erfahrungen im Projekt WeGe. In B. Behrensen \& M. Westphal (Hrsg.) Fluchtmigrationsforschung im Aufbruch. Methodologische und methodische Reflexionen (S. 275-300). Wiesbaden: VS Verlag für Sozialwissenschaften. https://doi.org/10.1007/978-3-658-26775-9

Coertjens, L., Brahm, T., Trautwein, C., \& Lindblom-Ylänne, S. (2017). Students' transition into higher education from an international perspective. Higher Education, 73(3), 357-369. https:// doi.org/10.1007/s10734-016-0092-y.

Colley, H. (2010). Time in learning transitions through the lifecourse: A feminist perspective. In K. Ecclestone, G. Biesta \& M. Hughes (Eds.), Transitions and Learning through the Lifecourse, (pp. 130-146.), New York, Abingdon, Oxon: Routledge.

Crea, T. M. (2016). Refugee higher education: Contextual challenges and implications for program design, delivery, and accompaniment. International Journal of Educational Development, 46, 12-22. https://doi.org/10.1016/j.ijedudev.2015.11.005.

DAAD (2018). Zukunftswege. Erfolge und Herausforderungen bei der Integration von Geflüchteten ins Studium. Berlin: DAAD.

Détourbe, M.-A. (2018). Crossing Boundaries: Insights into the Dynamics of Access to Higher Education, Immigration, and Languages. In M.A. Détourbe (Ed.) Inclusion through Access to Higher Education: Exploring the Dynamics between Access to Higher Education, Immigration and Languages, (pp. ix-xxv), Rotterdam/ Boston/ Taipei: Sense Publishers.

Détourbe, M.-A., \& Goastellec, G. (2018). Revisiting the issues of access to higher education and social stratification through the case of refugees: A comparative study of spaces of opportunity for refugee students in Germany and England. Social Sciences, (7), https://doi.org/10.3390/ socsci7100186.

Ecclestone, K., Biesta, G., \& Hughes, M. (2010). Transitions in the lifecourse: The role of identity, agency and structure. In K. Ecclestone, G. Biesta \& M. Hughes (Eds.), Transitions and Learning through the Lifecourse, (pp. 1-15). New York, Abingdon, Oxon: Routledge.

EHEA (n.y.). Social Dimension, http://www.ehea.info/page-social-dimension.

EHEA Education Ministers (2018). Paris Communiqué, http://www.ehea.info/Upload/document/ ministerial_declarations/EHEAParis2018_Communique_final_952771.pdf.

Fourier, K., Kracht Araújo, J., Latsch, K., Siemens, A., Schmitz, M., \& Grüttner, M. (2018). Integration von Flüchtlingen an deutschen Hochschulen: Erkenntnisse aus den Hochschulprogrammen für Flüchtlinge. Studienvorbereitung und Übergang ins Studium, DAAD.

Goastellec, G., \& Välimaa, J. (2019). Access to Higher Education: An Instrument for Fair Societies?. Social Inclusion, 7(1). doi: 1. https://doi.org/10.17645/si.v7i1.1841.

Grüttner, M., Schröder, S., Berg, J., \& Otto, C. (2018). Refugees on Their Way to German Higher Education: A Capabilities and Engagements Perspective on Aspirations, Challenges and Support. Global Education Review, 5(4).

Halkic, B., \& Arnold, P. (2019). Refugees and online education: student perspectives on need and support in the context of (online) higher education. Learning, Media and Technology, 44(3), 345-364. https://doi.org/10.1080/17439884.2019.1640739.

Harvey, A., \& Mallman, M. (2019). Beyond cultural capital: Understanding the strengths of new migrants within higher education. Policy Futures in Education, 17(5), 657-673. https://doi.org/ 10.1177/1478210318822180.

Keller, R. (2007). Diskurse und Dispositive analysieren. Die Wissenssoziologische Diskursanalyse als Beitrag zu einer wissensanalytischen Profilierung der Diskursforschung, Forum qualitative Sozialforschung/ Forum Qualitative Social Research (8(2), Art. 19), pp. 1-32. 
Keller, R. (2011). Wissenssoziologische Diskursanalyse, Wiesbaden: Springer Fachmedien.

Klaus, S. (2020). Biographische Konstruktionen zur Ambivalenz von Hochschulzugang und Fluchthintergrund, Wiesbaden: Springer Fachmedien Wiesbaden.

Ramsay, G., Baker, S. (2019). Higher Education and Students from Refugee Backgrounds: A MetaScoping Study, Refugee Survey Quarterly, 38(1), 55-82. https://doi.org/10.1093/rsq/hdy018.

Shapiro, S. (2018). Familial Capital, Narratives of Agency, and the College Transition Process for Refugee-Background Youth. Equity \& Excellence in Education, 51(3-4), 332-346. https://doi. org/10.1080/10665684.2018.1546151.

Sommet, N., Quiamzade, A., Jury, M., \& Mugny, G. (2015). The student-institution fit at university: interactive effects of academic competition and social class on achievement goals. Frontiers in psychology, 6. doi: 769. https://doi.org/10.3389/fpsyg.2015.00769.

Taylor, C., \& Harris-Evans, J. (2018). Reconceptualising Transition to Higher Education with Deleuze and Guatarri. Studies in Higher Education, 43 (7), 1254-1267.

Unangst, L. (2019). Refugees in the German higher education system: implications and recommendations for policy change. Policy Reviews in Higher Education, 3(2), 144-166. https://doi.org/ 10.1080/23322969.2019.1643254.

UNESCO (2018). Global education monitoring report, 2019: Migration, displacement and education: building bridges, not walls, UNESCO, https://unesdoc.unesco.org/ark:/48223/ pf0000265866.

UNHCR (2019a). Tertiary Education, UNHCR, https://www.unhcr.org/tertiary-education.html. Accessed 11/9/2019.

UNHCR (2019b). Figures at a Glance, UNHCR, https://www.unhcr.org/figures-at-a-glance.html. Accessed 11/9/2019.

United Nations (2015). Transforming our World: The 2030 Agenda For Sustainable Development, United Nations, https://sustainabledevelopment.un.org/content/documents/21252030 $\% 20$ Agenda\%20for\%20Sustainable\%20Development\%20web.pdf. Accesses 11/7/2019.

Walker, M. (2019). The Achievement of University Access: Conversion Factors, Capabilities and Choices. Social Inclusion, 7(1), 52. https://doi.org/10.17645/si.v7i1.1615.

Open Access This chapter is licensed under the terms of the Creative Commons Attribution 4.0 International License (http://creativecommons.org/licenses/by/4.0/), which permits use, sharing, adaptation, distribution and reproduction in any medium or format, as long as you give appropriate credit to the original author(s) and the source, provide a link to the Creative Commons license and indicate if changes were made.

The images or other third party material in this chapter are included in the chapter's Creative Commons license, unless indicated otherwise in a credit line to the material. If material is not included in the chapter's Creative Commons license and your intended use is not permitted by statutory regulation or exceeds the permitted use, you will need to obtain permission directly from the copyright holder.

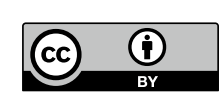

